\title{
Editorial
}

\section{Welcome to the Associate Editors}

As we announced in our previous issue, in 2012 the JAOS will have the precious help of the Associate Editors appointed by Dr. José Carlos Pereira, the current Dean of the Bauru School of Dentistry, University of São Paulo. Now that our online submission system is open for new submissions, we take advantage of this opportunity to present our Associate Editors and their respective areas:

- Basic Sciences: Gustavo Pompermayer Garlet and Carlos Ferreira Santos

- Endodontics: Ivaldo Gomes de Moraes, Flaviana Bombarda de Andrade and Marco Antonio Hungaro Duarte

- Orthodontics: Guilherme Janson and Daniela Gamba Garib Carreira

- Periodontology and Implantology: Adriana Campos Passanezi Sant'ana and Maria Lúcia Rubo de Rezende

- Radiology: Ana Lúcia Alvares Capelozza and Izabel Regina Fischer Rubira-Bullen

- Operative Dentistry and Dental Materials: Rafael Francisco Lia Mondelli, Maria Teresa Atta and Linda Wang

- Stomatology and Pathology: José Humberto Damante and Vanessa Soares Lara

- Prosthodontics: Luiz Fernando Pegoraro, Paulo César Rodrigues Conti and Karin Hermana Neppelenbroek

- Pediatric Dentistry: Maria Aparecida de Andrade Moreira Machado and Thais Marchini de Oliveira Valarelli

- Cariology and Community and Preventive Dentistry: Marília Afonso Rabelo Buzalaf and José Roberto Pereira Lauris

- Oral Surgery: Eduardo Sant'ana and Osny Ferreira Junior

- Speech Pathology and Audiology: Maria Inês Pegoraro-Krook and Kátia de Freitas Alvarenga.

The Associate Editors are more than welcome! We hope to develop a great team work!

With our best regards,

\section{Carlos F. Santos}

DDS, MSc, PhD, Professor

Editor-in-Chief

Journal of Applied Oral Science 